\title{
Correction: Accidental aspiration of a solid tablet of sodium hydroxide
}

Boonekamp C, Voruz F, Fehlmann C. Accidental aspiration of a solid tablet of sodium hydroxide. BMJ Case Rep 2018; doi:10.1136/bcr-2018-224213.

The substance ingested by the patient described in the case report was sodium hypochlorite (Bleach, $\mathrm{pKa}=7.52$ ) and not sodium hydroxide (Caustic soda, $\mathrm{pKa}=14.8$ ).

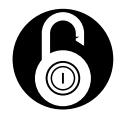

\section{OPEN ACCESS}

Open access This is an open access article distributed in accordance with the Creative Commons Attribution Non Commercial (CC BY-NC 4.0) license, which permits others to distribute, remix, adapt, build upon this work noncommercially, and license their derivative works on different terms, provided the original work is properly cited, appropriate credit is given, any changes made indicated, and the use is non-commercial. See: http://creativecommons.org/licenses/by-nc/ $4.0 \%$

(c) BMJ Publishing Group Limited 2018. Re-use permitted under CC BY-NC. No commercial re-use. See rights and permissions. Published by BMJ.

BMJ Case Rep 2018. doi:10.1136/bcr-2018-224213corr1

A) Check for updates

Copyright 2018 BMJ Publishing Group. All rights reserved. For permission to reuse any of this content visit http://group.bmj.com/group/rights-licensing/permissions.

BMJ Case Report Fellows may re-use this article for personal use and teaching without any further permission.

Become a Fellow of BMJ Case Reports today and you can:

- Submit as many cases as you like

- Enjoy fast sympathetic peer review and rapid publication of accepted articles

- Access all the published articles

- Re-use any of the published material for personal use and teaching without further permission

For information on Institutional Fellowships contact consortiasales@bmjgroup.com

Visit casereports.bmj.com for more articles like this and to become a Fellow 